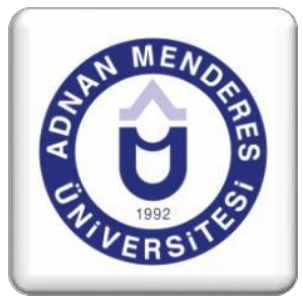

\title{
Değer Eğitiminde Kısa Filmlerden Yararlanma: Örnek Bir Uygulama ${ }^{1}$
}

\author{
Elif ALADAĞ $\breve{G}^{2}$, Burcu KARAMAN ${ }^{3}$
}

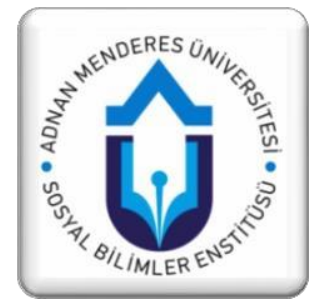

\section{ÖZET}

Kısa filmler, uzunluğu ülkelere göre farklılık gösteren ama genellikle $35 \mathrm{~mm}$ filmlerde bir ile üç makara arasında değişen filmlerdir. Kısa filmleri uzun metrajlı filmlerden ayrılan özelliği süresi ve öykü yapısıdır. Kısa filmlerin süresiyle ilgili net bir tanım olmasa da genel olarak 5-17 dakika arasında sürebilir. Öykü yapısındaki fark ise anlatımı yalın, sade ve kısa süre içinde anlam yoğunluğunu verebilmesidir. Bu çalışmanın amacı ilgili alan yazın taranarak kısa filmlerin ne olduğu ve eğitimde nasıl kullanılması gerektiğine yer verilmesidir. Ayrıca eğitimde kısa film kullanımının değer eğitimi açısından önemi irdelenmeye çalışılmıştır. Çalışma sonunda kısa filmlerin değer öğretiminde kullanımı ile ilgili örnek bir uygulama sunulmuştur. Örnek uygulamadaki kısa filmler EBA' da yer alan ödüllü kısa filmler içinden çocuğa görelik ilkesi ve kısa filmlerde bulunması gereken özellikler göz önünde bulundurularak seçilmiştir.

Anahtar Sözcükler: Sosyal Bilgiler, Değer Eğitimi, Kısa Film.

\section{The Use of Short Films in Value Education: An Application Example}

\section{ABSTRACT}

Although, short films could show difference in duration, they are generally ranging from one to three bobbins in $35 \mathrm{~mm}$ films. The distinctiveness of short films from full length films is time and plot. There is no exact definition about short films duration but generally takes 5 to 17 minutes. The plot has, unlike full length films, a plain expression and give the main meaning in a short time. The aim of this study is to find out the information about the short films and how to use them in education by literature view. In additon, the importance of using short films in value education will be examined. In the last part of the study an example lesson plan is presented for using short films in value education. The films in the plan are selected among the awarded short films on the EBA platform by taking into consideration characteristics of short films and suitability for child principle.

Keywords: Social Studies, Value Education, Short Film.

\footnotetext{
${ }^{1}$ Bu çalışma 1-3 Şubat 2018 tarihinde Kuşadası'nda gerçekleştirilen XV. European Conference on Social and Behavioral Sciences'da sözlü bildiri olarak sunulmuştur.

${ }^{2}$ Doç. Dr., Adnan Menderes Üniversitesi, Sosyal Bilimler ve Türkçe Eğitimi Bölümü, ealadag@adu.edu.tr

${ }^{3}$ Adnan Menderes Üniversitesi, Sosyal Bilimler Enstitüsü, Yüksek Lisans, burcukaraman43@gmail.com
} 


\section{Giriş}

Sosyal Bilgiler değişen ülke koşullarında her türlü bilgiyi alan, eleştirel bakış açısıyla süzgeçten geçirerek düzenleyen, problem çözme becerisine sahip olan vatandaş yetiştirmek amacıyla, sosyal bilimlerden aldığı bilgileri bir araya getiren öğretim programıdır (C. Öztürk, 2009). Sosyal bilimlerin verilerini öğrencilerin düzeyine göre sadeleştiren ve sosyal hayata uyum sağlamada ihtiyaç duyacakları bilgi, beceri, değer ve tutum kazandıran Sosyal Bilgiler dersi insan yaşamıyla bir bütündür. Hayat ile iç içe olan Sosyal Bilgiler dersinin temel amaçlarından biri iyi bir vatandaş yetiştirmektir. Bu açıdan öğrencilerin, bilgi ve beceri açısından donanımlı olması, güncel olayları takip edebilmesi, bireysel, toplumsal ve kültürel yaşamda meydana gelen ve gelebilecek olan sorunlarla başa çıkabilmesi, olaylara eleştirel gözle bakabilmesi ve yaşadığı dünyayı doğru bir şekilde anlamlandırabilmesi gerekmektedir. Bunun için öğrenme ve öğretme ortamlarının çok iyi bir şekilde düzenlenmesi ve öğrencilerin derslere aktif katılımının gerçekleşmesi gerekmektedir.

Öğrenme ve öğretme sürecinde kullanılan araç-gereçler, yöntem-teknikler bu sürecin daha etkili ve verimli bir şekilde geçmesine yardımcı olmaktadır. Öğrenme ve öğretme sürecinin başarılı olabilmesi, yöntem ve tekniklerin gerekli araç gereçlerle uygun zamanda desteklenmesine bağlıdır. Öğrenmenin gerçekleşmesinde etkili olan faktörlerden biri olan araç-gereçler doğru kullanıldığında, öğrencilerin öğrenme ve öğretme sürecine aktif katılmalarına, anlamlı ve kalıcı öğrenmelerin gerçekleşmesine yardım etmektedirler (Yaşar ve Gültekin, 2006).

Amerikalı eğitimci Edgar Dale, öğrenme işlemine katılan duyu organlarının sayısının ne kadar fazla ise o kadar iyi öğrenileceğinden ve o kadar geç unutulacağından bahsetmiştir (Çilenti, 1979: 39 akt: Öztaş, 2007). Öğrenme öğretme sürecinde birden fazla duyu organlarına hitap ederek yapılan etkinlikler öğrenmeyi arttırarak kalıcı öğrenmenin gerçekleşmesine yardımcı olmaktadır. Bu, öğretimde görsel-işitsel materyal kullanılması anlamına gelir.

Eğitim öğretim ortamında ulaşılmak istenen hedeflere varmada görsel ve işitsel materyallerin kullanımı önemlidir. Öğrenilenlerin daha kalıcı olmasını, öğrencilerin derslere daha iyi bir şekilde adapte olabilmesini, öğrencilerin dikkatlerinin dağılmamasını sağlamaktadır. $\mathrm{Bu}$ eğitsel materyallerin sınıf içerisinde belirli bir öğretim planı dâhilinde yapılması gereklidir. Eğer düzenli bir şekilde yerinde ve zamanında kullanılamazsa öğrenmeyi kolaylaştıramadığı gibi öğrencilerin dikkatini dağıtabilir ve materyaller ile asıl anlatılmak istenilen konuya odaklanmaları engellenebilir. Bunun önüne geçebilmek için, öğretmenler derse getirecekleri materyallerin seçiminde özenli davranmalı ve bu materyalleri nasıl kullanması gerektiğinin farkında olmalıdır. Öztaş (2008) derste kullanılabilecek olan materyallerin fotoğraflar, kavram haritaları ve filmler olabileceğini söylemiştir. Filmler, eğitimde yaygın olarak kullanılan görsel - işitsel araçlar arasında yer alır. Film, öğrencinin her zaman ilgisini çeker ve gerçek yaşamda göremeyecekleri olay ya da sahneleri görme olanağı sağlar. Bruner (2008/2014) filmleri ve kısa filmleri doğrudan deneyim sunan materyaller olarak değil dolaylı olarak sunan araçlar olarak görmüştür. Ona göre filmler öğrenme ve öğretme sürecini zenginleştirmektedir. Çakıroğlu, Güven ve Akkan (2008), bir defa üretilen bir nesneden defalarca faydalanabilme, tekrar kullanılabilirlik, erişilebilirlik gibi birçok fayda ve özelliğin, eğitsel amaçlı kullanılan kısa filmlerle örtüştügünden bahsetmektedir. Filmlerin derslerde etkili olmasının önemli nedenlerinden bir tanesi de yeni nesillerin görsel medyaya aşina olmalarıdır. İzleyiciler, video, film gibi görsel medyanın etkisine maruz kalmaktadırlar (Alvare v.d. 2004; akt: Birkök, 2008). 


\subsection{Kısa Film Nedir?}

Kısa film 1900'lü yılların başında ortaya çıkmaya başlamıştır. TDK (2018), kısa filmi "Sinema uzunluğu ülkeden ülkeye, genellikle $35 \mathrm{~mm}$ ' lik filmlerde bir ile üç makara (300$1.000 \mathrm{~m}$ ) arasında değişen, çok kisa film ile orta uzunlukta film arasında yer alan film" olarak tanımlamıştır. Kısa filmlerin öyküsü drama, belgesel ya da deneysel olabileceği gibi canl1-aksiyon ya da canlandırma (animasyon) olabilir.

Kısa filmler belirli bir süre içerisinde anlatımın gerçekleştirildiği, temelde uzun metrajlı olmayan filmleri temsil etmektedir. Bir filmi kısa film olarak tanımlamak için gerekli olan temel faktör uzunluğudur. Kısa filmlerin süresinin uzunluğunun sinırlamasılyla alakalı, üzerinde görüş birliği bulunmamaktadır ("What is the Difference Short Films", t.y.). Buna rağmen Sinema Sanatları ve Bilimler Akademisi (2013) kısa filmleri, tüm kredileri de içeren 40 dakikalık bir çalışma süresi olan orijinal bir hareketli resim olarak tanımlamaktadır (akt: Gill ve College, 2014).

Güzeloğlu (2008), kısa filmlerin başlı başına bir sinema olduğunu ve süresinin 1 ile 6 veya 7 dakika arasında değişebileceğini ifade etmiştir. Evci'ye (2007) göre kısa film "süresi kısa olan filmlerdir." Teknik olarak 30 dakika ve onun altında yer alan filmleri kısa film olarak değerlendirmektedir. Kısa filmler konu çerçevesinde belirlediği süre içinde çok şey ifade eden ve son yıllarda geniş bir kitleyi etkisi altına alan özgür yapitlardır. Uzun metrajlı filmlere göre kısa filmlerin en başta kıyaslanan özelliği süresidir. Bunun dışında kısa filmler yapısı gereği konunun özünü veren, zekâ içeren ve sözü çok fazla uzatmadan çarpıcı bir şekilde ifade eden özellikleriyle de uzun filmlerle kıyaslanabilmektedir.

Uzun metrajlı filmlerle arasında ters orantı vardır. Süre kısaldıkça yapılacak artistik düzen ve diğer tüm şeyler çok daha doğru ve iyi olması gerekliliğine doğru götürür. Çünkü anlatım zamanı oldukça kısa ve olabildiğince özgürdür. Etikan (2003) kısa filmlerle ilgili yaptığı bir söyleşi de kısa ama etkileyici olan öykülerin yer aldığı, uzun metrajla uygun düşmeyen, görsel belgeler ve animasyonların yaratım ortamını oluşturduğundan bahsetmektedir. Ona göre kısa filmleri uzun süreli filmlerden ayıran en büyük özellik yalınlık ve zekâ yoğunluğu içermesidir.

Kısa film az bir süre içerisinde çok şey anlatabilme zorunluluğu getirmektedir. Yönetmen anlatacağı şeyi çarpıcı bir dille, açık ve sade biçimde ortaya koymaktadır (Yeşilyurt, 2016).

Kısa filmlerin normal uzunluktaki filmlerden fark1 sadece zaman açısından az olması değildir. Kısa filmin öyküsü de normal uzunluktaki filmlerden farklıdır. Anlatımı yalın ve açıktır. Bunun dışında gönüllü bağımsız yönetmenler tarafından çekilmektedirler. Uzun metrajlı filmlere göre daha düşük bütçeli ve çoğunlukla ticari olmayan filmlerdir. Uzun metrajlı filmlerde oyuncuların çokluğu, mekân, maddi kaynak, para kazanabilme gibi unsurların varlığı ön planda olabilmektedir. Abono (2016) uzun metrajlı filmlerden farklı olan kısa film yapımının başarılı olabilmesi durumunda büyük miktarda izleyiciye ulaşmasının mümkün olacağını söylemektedir.

Kısa filmlerin başarılı olmasında yapı önem arz etmektedir. Yapı kısa filmleri oluşturan tüm unsurların organizasyonu ve filmin öyküsünü destekleyen her şeyini tutturan bir iskeledir (Nash, 2012/2013). Yapısı gereği senaryo, 1şık, ses, kurgu, oyuncu öğelerden oluşmaktadır. Çünkü bütün öğeler filmin bütününü meydana getirmektedir. Bu ögelerin bir bütün içinde uyumlu bir şekilde kullanılması kısa filmin kalitesinin sağlanması açısından önemlidir. 


\subsection{Kısa Film Türleri}

Kısa süreli filmler 6 türe ayrılmaktadır. Bu türler: Kurmaca, belgesel, deneysel, animasyon, reklam- tanıtım filmi, video kliptir.

\subsubsection{Kurmaca}

Film öyküleri planlanmış ya da planlanmamış olabilir. Kısa filmin kurmaca ya da diğer adıyla konulu film türünde, öncelikle bir önerme ve bu önerme doğrultusunda bir öyküden hareket edilir. Ancak kısa filmde ele alınan öykünün dramatize edilmesi, uzun çevrimli filmlerden farklı olarak daha çarpıcı öğelerin kısa bir anlatım yoluyla aktarılması sonucu gerçekleşir (S. Öztürk, 2009).

\subsubsection{Belgesel}

Belgeseller belli bir amaca hizmet etmektedirler. Belgesel film, sanat ve belgenin gözleme dayanarak elde edilebileceği bir film türüdür. Belgesel filmde, ele alınan bireylerin sahip oldukları görüş açısının da aynı yönde düşünülmesi gereklidir. Bu sebeple toplumun yaşamını sürdürmek için kullanılan bir sanat türüdür. Belgesel filmin iletişim aracı olarak kullanıldığını düşünürsek toplumun gerçeğini gösterdiğini söyleyebiliriz. Özön (1981), belgesel filmi; "Kurmacaya yer vermeyen ya da pek az yer veren konusunu doğrudan doğruya doğadan alan dışımızdaki dünyayı, gerçeğe elden geldiğince uyarak, nesnel bir tutumla yansıtmaya çalışan film türü” olarak tanımlamaktadır.

\subsubsection{Deneysel}

Deneysel film, sinema tarihçilerinin çoğu tarafından, sinemada o ana kadar kullanılmamış konuları, ilginç ve değişik tekniklerle ele alarak yapılan ve sinema sanatçılarına yeni ufuklar açmayı hedefleyen film türü olarak tanımlanmaktadır.

Deneysel sinema açısından farklı ve yeni bakış açılarının, farklı oyunculuk tarzlarının ve kamera hareketlerinin gelişiminde ve yeni yeteneklerin keşfedilmesinde önemli bir yerdedir (Evci, 2007).

\subsubsection{Animasyon}

Animasyon, canlandırma demektir (TDK, 2018). Canlandırma 1930'lu yıllarda Disney ve çağdaşı olan sanatçıların filmlerinin Türk sinemalarında gösterime başlamasıyla Türkiye'ye girmeye başlamıştır. $\mathrm{Bu}$ filmlerle ilgilenen Türk sanatçıları, karikatür canlandırma sinemasına ilgi duymuş ve çalışmalar başlatmışlardır (Okumuş, 2014).

\subsubsection{Reklam-Tanıtım Filmi}

Etkili iletişim biçimi olarak tüketicileri bir mal ya da hizmetin varlığı hakkında uyarmak ve o mala, markaya, hizmete veya kuruma olumlu bir tutum yaratmak amaciyla mesajların hazırlanmasıdır. Hazırlanan bu mesajların türlü medyalarda ücretli olarak yayınlanması biçiminde tanımlanan reklam, hem tüketiciye bilgi aktarır hem de tüketiciyi ürüne ya da hizmeti kullanmaya, satın almaya yönlendirir. Bir başka deyişle, tüketiciyi ürünü veya hizmeti kullanmaya ikna eder (Kaynar, 1993). 


\subsubsection{Video Klip}

Video klip, şarkı vb. müziklerin izleyiciye ulaşması amacıyla çekilen işitsel-görsel olarak değerlendirilen bir kısa filmdir.

\section{Kısa Filmlerin Sosyal Bilgiler Eğitiminde Kullanımı}

Eğitim ortamında öğretim amacıyla hazırlanan filmler görme ve işitme duyularına hitap ettiği için iyi bir öğretim aracıdır (Alıcıgüzel, 1998). Filmleri derste kullanabilmek için gerekli ortamın sağlanması, öğrencilerin o derse karşı güdülenmesini sağlamakta ve öğrencilerin ilgisini çekmektedir.

Alan yazın incelendiğinde eğitim ve öğretim faaliyetleri içerisinde film kullanımının öğrencilerin somut ve kalıcı öğrenmeler sağlama, derse güdüleme, öğrencilerin ilgisini çekme, zaman ve mekân açısından daha esnek olmasını sağlama, öğrenmeyi somutlaştırma pek çok faydaları olduğu görülmektedir (Alkan, 1998; Akpınar, 2005). Derslerde filmler gerekli yerlerde durdurularak öğrencilere sorular sorulabilir ve gerekli ipuçları öğrencileri pasif bir durumdan etken duruma geçirilebilir. Öğrenci kafasında tam olarak netleştiremediği olay, olgu ve kavramları filmler sayesinde somutlaştırarak anlamlı öğrenmeleri gerçekleştirebilir. Bu açıdan filmler ile kısa filmlerde de ortak özellikler bulunmaktadır. Film ve kısa filmler hem bir öğrenciye kişisel olarak, hem de öğrenci gruplarına toplu halde gösterilebilir. Renkli ve hareketli olması öğrencilerin ilgisini çekmekte ve dikkatlerinin kolaylıkla toplanmasını sağlamaktadır. İstenildiği zaman durdurulabilmekte ve öğrencilerle birlikte yorumlanabilmektedir. Öğrenciler tarafindan bağımsız ve bireysel olarak kullanılabilmesi açısından önemli materyallerdir. Bu sayede öğrenci dersi kaçırdığı zaman veya tekrar etmek istediğinde ya da ilgilendikleri zaman kullanılabilmektedir. Öğrenciler film ve kısa filmler sayesinde, fiziksel uzaklık nedeniyle sınıf ortamına getirmenin mümkün olmadığı, ulaşamadıkları yer, mekân, kültürleri izleyebilmekte, insanları gözlemleyebilmekte ve doğa olayları gibi pek çok şeyi görme şansına sahip olabilmektedir. Filmler, öğrencilerin birden fazla duyu organına hitap ettiği için öğrenmeler daha kalıcı olmaktadır. Sadece bilişsel değil duyuşsal alandaki becerilerinde gelişimini sağlamaktadır. Gerçek hayatta olgu ve olayları görsel ve işitsel olarak sunabildiği için bu alandaki gelişimine de yardımcı olmaktadir.

Eğitim ve öğretim ortamında kullanımı fayda sağlayacak kısa filmlere ulaşmak günümüzde kolaylaşmıştır. Teknoloji, iletişim ve internet ağları üzerindeki gelişmeler öğretmenlere bu konuda yardımcı olmaktadır. Öğretmenlerin kısa film, çizgi film gibi türleri bulma imkânları da genel içerikli internet sitelerinde ve öğretmenler tarafindan oluşturulan paylaşım sitelerinde artmıştır (Korkmaz, 2014). İnternette yer alan "Eğitim Bilişim Ağı" yani EBA gibi eğitim platformunda da kısa filmler bulunmaktadır.

Akbaş (2011) kısa filmleri, öğretim programındaki kazanımlara yönelik olduğunda 'eğitsel film' olarak isimlendirmiştir. Buna ek olarak öğretmen adayları tarafından çekilen kısa filmlerin eksik ve faydalı yönlerinin ortaokul öğrencileri tarafından değerlendirilmeye alındığı çalışmasında, kısa filmlerin kısa sürede az ve öz bilgi verme, farkındalık oluşturma gibi katkılarından söz etmektedir. 
Eğitim açısından kısa filmler normal uzunluktaki filmlerle karşılaştırıldı̆̆ında;

- Genellikle zaman açısından (5-15 dakika) filmlere göre daha kısadır. Bu nedenle öğrenciler sıkılmaz.

- Filmler uzun olduğu için tamamının sınıfta izlenmesi zordur ve zaman alır. Kısa filmlerin ise tamamı ders esnasında izlettirilebilir.

- Kısa filmlere ayrılan süre az olduğu için filmle alakalı ders içi tartışma, değerlendirme gibi etkinliklere daha fazla zaman kalabilmektedir. Dolayısıyla öğrenmeye de daha fazla zaman ayrılacaktır.

- Film ve kısa filmler kullanılacağı zaman ders öncesinde öğretmenin öğrencilerin seviyelerine, konunun uygunluğuna göre bir film seçebilmesi yapabilmesi için hazırlık yapması gerekmektedir. Bu açıdan normal uzunluktaki bir filmi seçerken öğretmenin filmin tamamını izlemesi gerekmekte ve bu da daha fazla zaman ayırmasını gerektirmektedir. Kısa filmler ise süre açısından daha avantajlı olduğundan ögretmenlere zaman kazandırabilmektedir.

- Ö̈̆retmen filmlerde gerekli gördüğü kısımları öğrencilerine izlettirebilmektedir. Filmlerde belirli bölümlerin atlanarak izlenmesi öğrencilerin konunun tam olarak anlayamamasına, bir bütün oluşturamamasına neden olabilir. Ya da öğrencinin merak ve ilgisinin öğrenilecek konudan çok filmin bütününe kaymasına neden olabilir. Oysa kısa filmin tamamının bir seferde izletilmesi bu gibi durumların dezavantajlarını giderebilir.

Filmlerin Sosyal Bilgiler dersinde etkili ve verimli kullanımıyla ilgili olarak Öztaş (2007), sürecin iyi bir şekilde planlanmasının öneminden ve filmlerin konuya, öğrencilerin seviyesine, kazandırılması gereken hedef davranışlara uygun olması gerektiğinden söz etmektedir. Uzun süreli filmlerde olduğu gibi kısa filmlerin kullanımıyla ilgili olarak da bu sürecin iyi bir şekilde planlanması gerekmektedir.

Planlı bir kısa film izleme etkinliği üç bölümden oluşmaktadır:

1. Ön Hazırlık

2. Uygulama

3. Değerlendirme

\section{1.Ön Hazırlık}

Öğretmen dersin kazanım, beceri, kavram ve değerlerine uygun olarak kullanacağı kısa filmi belirler. Öğretmen, medyada mevcut kısa filmlerden seçim yapabileceği gibi, kendisi de kısa bir film hazırlayabilir. Konuya uygun olarak kısa filmle ilgili etkinlik sürecini planlar. Ders öncesinde kısa filmi izlettireceği akıllı tahta, projeksiyon, internet, flash bellek gibi gerekli materyallerin ders için uygun bir hale getirilmesi ve gerekli kontrollerinin yapılması gereklidir.

\section{Uygulama}

Bu aşamada film başlamadan önce öğretmen kısa filmin izlenmesindeki amaçlarla ilgili olarak öğrencileri bilgilendirmelidir. Öğretmenin kısa filmin amacına göre öğrencilerin 
dikkatini çekmek, merak uyandırmak ve konuya odaklanmalarını sağlamak için gerekli açılamalar yapabilmesi, bir soru sorabilmesi veya o konu ile ilgili öğrencilerin düşünmelerini sağlayabilmesi beklenmektedir.

Filmlerle ilgi kavramlar öğrenciye önceden açıklanmalı veya onların o bilgilere daha önceden ulaşmaları sağlanmalı, film gösterimiyle ilgili konu anlatımı ve yapılacak etkinliklerin süresi iyi ayarlanmalıdır (Öztaş, 2007).

Gerekli açıklamalar yaptıktan sonra kısa film izletilir. Öğrencilerin sorusu olup olmadığı sorulduktan sonra değerlendirme aşamasına geçilir.

\section{Değerlendirme}

Değerlendirme aşamasında kısa filmde anlaşılmayan noktaların açıklamaları yapılmalı, gerekli görülürse tekrar izletilmelidir. Öğrencilerin izledikleri kısa filmler üzerine konuşmaları, tartışmaları ve yorumlar yapması beklenmektedir. Öğretmen bu konuda öğrencilerin fikirlerini ve izledikleri film ile ilgili neler düşündüklerini sorabilir. Ön hazırlık aşamasında planladığı sorular varsa öğrencilere sorarak konunun daha da pekişmesi sağlanabilir.

Tartışma ve yorumlar yapıldıktan sonra izlenmiş olan kısa filmle ilgili resim, şiir, hikâye, masal, mektup, drama gibi etkinliklerle konunun pekişmesini sağlayabilir.

O'Connor (1987) filmler seyredildikten sonraki süreçte sınıfta yapılan tartışma ve yorumların bir metin okunduktan sonra yapılan yorum ve tartışmalardan daha verimli olduğunu söylemiştir. Filmle ilgili yaptığı tartışmalarda öğrencilerin etkinliklere daha kolay katıldıklarından bahsetmiş̧ir (akt: Öztaş, 2007). Bu yüzden kısa filmlerde değerlendirme aşaması konunun gerçek anlamda hedefine ulaşmasını sağlaması açısından önemlidir.

MEB, son yıllarda kısa filmlerin eğitim ortamında kullanımıyla ilgili çalışmalar yapmaktadır. EBA bu çalışmaların başında gelmektedir. Lise öğrencileri için hazırlanan interaktif eğitim portalı daha sonra ilkokul ve ortaokul öğrencileri için de hazırlanmaya ve EBA' nın kapsamı genişletilmeye çalışılmıştır. EBA üzerinde belirli temalar veya konularla ilgili kısa filmler yer almakta ve bunlar dışında kısa film yarışmaları düzenlenmektedir.

\subsection{Kısa Film Kullanımının Avantajları}

Kısa filmler uygun bir şekilde kullandıklarında etkili ve faydalı olmaktadır. Etkili kullanıldığında öğrencilerin anlama, yaratıcı düşünme, eleştirel düşünme becerisini geliştirmektedir. Öğrencilerin konuları kolay bir şekilde hatırlamalarına olanak tanımaktadır. Kısa filmler genellikle ticari bir amaçla yapılmadıklarından ücretsizdir. Zaman açısından kısa oldukları için öğrencilerin istenilen konuya odaklanmalarını sağlayabilmektedir.

Öğrencilerin gözlem gücünün artmasına, insan ilişkilerini değerlendirebilme, bireysel ve toplumsal olayları karşıllklı olarak neden sonuç ilişkileriyle birlikte farklı görüşleri de ekleyerek yorumlayabilme ve değerlendirebilmeyi sağlayabilmektedir. Öğrencilerin kendi kısa filmlerini çekebilmeleri sorumluluk duygularının gelişmesini, sorumluluk alma, sorumluluklarını yerine getirme ve grup çalışmaları gibi deneyim kazanmalarını sağlayabilmektedir Aynı zamanda konunun bir parçası olduğunu hissederek aktif katılımının gerçekleşmesine katkı sağlayabilir (Kabadayı, 2012). 
Alanyazında kısa filmlerle ilgili yapılan çalışmalar, eğitimde kullanımının avantajlarını destekler niteliktedir. Önen Öztürk'ün (2017), Fen Bilgisi öğretmen adaylarıyla eğitsel kısa filmler üzerine yaptığı çalışmasında 51 öğretmen adayıyla fen-toplum temelli 10 farklı kısa film hazırlanmıştır. Araştırma, öğretmen adaylarının kısa filmlerle fen kavramlarını doğru bir şekilde kullandığını, fen ve toplum ilişkisini kurulabildiğini, filmleri sınıf seviyesine uygun bir şekilde günlük hayatla ilişkilendirebildiğini ve hazırlanan filmlerin anlaşılır bir dile sahip olduğunu ortaya koymaktadır. Aynı zamanda bu çalışmada öğretmen adayları kısa filmlerin öğretim sürecini kolaylaştırma, ilgi çekme, eğlenerek öğrenebilme ve sorgulama becerisi gibi olumlu nitelikleri bulunduğu da ortaya koymuştur.

Korkmaz'ın (2017) din dersi öğretmenlerinin bir öğretim materyali olarak film/video kullanma durumlarını ortaya koymayı amaçladığı çalışmasında araştırmaya katılan öğretmenlerin en çok kullandıkları film türünün kısa film ve videolar olduğunu ve öğretmenlerin bu materyalleri daha çok konunun içeriğini zenginleştirmek amacıyla kullandıkları anlaşılmıştır. Bunları dersin sonunda konuyu ve üniteyi toparlayabilmek ve yeni konuya dikkat çekme amaçları izlemiştir.

Şahin'in (2015), “Ortaokul öğrencilerinin dinleme becerilerinin geliştirilmesinde kısa filmlerin etkisi" başlıklı çalışmasında deney grubunda uygulanılan tekniklerin kontrol grubunda uygulanan tekniğe göre öğrencilerin dinlediğini anlama ve hatırlama düzeylerine katkı sağladığını ortaya koymuştur. Şahin, kısa filmlerin işitsel ve görsel olarak erişilebilmesinden dolayı dinleme becerisi eğitiminde materyal olarak kullanılmasını önermektedir.

\subsection{Kısa Film Kullanımının Sinırlılıkları}

Dersin konusuna uygun kısa film bulmak da bazen zor olabilir. Kisa film kullanımıyla ilgili dersin iyi bir şekilde planlanmaması, öğretmeninin nasıl kullanacağını bilememesi kısa film kullanımının sınırlılıklarındandır. Ayrıca kısa filmini çekmek isteyen öğretmen ve öğrenciler için kısa film çekimiyle ilgili eğitim eksikliğinden dolayı senaryo yazma, çekim ve düzenleme için ayrılan süresinin uzaması gibi durumlar söz konusu olabilmektedir (Kabaday1, 2012).

\section{Kısa Filmlerin Değer Eğitiminde Kullanılması}

Değer, "Halkın, kendi yarattığı ya da benimsediği kültür ürün ve olaylarından her birine biçtiği değer" olarak tanımlanmaktadır (TDK, 2018). Değer; inanılan, arzu edilen ve davranışlar için bir kıstas olarak kullanılmakta olan olgulardır (Öztürk Samur, 2011). Bir şeyin öneminin belirlenmesini, olması gereken ile olanın ayrımını içeren bir ölçü olarak ifade edilmektedir.

Değerler insanların davranışlarını belirleyerek onlara yön verir. Tercih etme durumlarında insanları yönlendirir. Neyin tercih edilmesi gerektiği neyin tercih edilmemesi gerektiği durumları belirleyerek insanların kararlarını yönlendirmektedir. Değerler bu konularda toplumun tercihleri hususunda etkili bir araç olmaktadır (Özgökbel Biliş, 2011).

Tozlu'ya (1992) göre değerler, insanların düşüncelerinin meydana getirmesiyle oluşan ve toplumun maddi gerçeğin ötesinde manevi olarak taşıma gücüdür. Toplum içinde bireyleri bir arada tutma ve varlığını devam ettirme gücü sağlar. Sosyal bilimlerin hemen hemen her alanında yaygın olarak yer alan ve üzerinde önemle durulan bir kavramdır. 
Değer eğitiminde çocukların kendilerine ve topluma yararlı olacak temel değerleri bireysel ve sosyal gelişimleri ile birlikte kazanmaları amaçlanmaktadır. Çocuğun doğuştan getirdiği en iyi yönünü ortaya çıkarabilmek ve onları kötü davranışlardan koruyarak kendisi ve çevresiyle barışık bireyler yetiştirmeyi amaçlar (Aydın ve Akyol Gürler, 2014). Bireyin kendisine ve çevresine karşı olumlu değer algısı geliştirebilmesini, sorumlulukların farkına vararak toplumsal düzenin korunmasını sağlayabilmesi değer eğitiminden geçmektedir.

Günümüzde değer eğitimi örtük program çerçevesinde ya da müfredata uygun programlar, etkinlikler ve seçmeli ders olarak bazı okullarda gerçekleşmektedir. Sosyal Bilgiler müfredata uygun bir şekilde değerlerin açıkça yer aldığı, programların ve etkinliklerin hazırlandığı derslerin başında gelmektedir. Sosyal Bilgiler bir değer eğitim dersidir (Gömleksiz ve Cüro, 2011).

Öğrencilere yönelik derslerde değer eğitimine yönelik yapılan çalışmalarda drama, kısa hikâyelerin sınıfta okunması, resim yarışmaları, değer köşesi oluşturmak gibi uygulamalar bulunmaktadır. Değer eğitimi uygulamalarında bu gibi etkinliklerin gerekli materyallerle desteklenmesi bireyin ve toplumun gelişimi açısından önemli olabilmektedir.

"Filmler, film şeritleri, kayıtlar, teypler, el kitapları, hikâye kitapları, mini kurslar ve bütün müfredatların içinde bulunduğu materyaller, değerler ve değerler öğretiminin çeşitlendirilmesi amacı için üretilmekte ve dağıtılmaktadır" (Superka vd. 1976 akt: Aladağ, 2009). Bruner (2008/2014) öğretme sürecinin zenginleşmesine film ve kısa filmlerin katk1 sağladığından bahsetmiştir. Değer eğitiminde drama, hikâye okuma, resim yarışmaları şeklindeki etkinlikler gibi film ve kısa filmlerin de kullanılması fayda sağlayabilmektedir. Kısa filmler ile öğrenciler kendi tecrübe ve olayların muhakemesini gözlem yoluyla yapabilir, model alınabilecek davranış ve tutumları örnek alabilir. Bunlarla birlikte kısa filmler öğrencilerin iyi, güzel, doğru davranışları görmesini ve bunları kendi düşünme sistemiyle belirli bir süzgeçten geçirebilmesini, var olan değerlerle alakalı olarak sınıf ortamında gerekli tartışma ve ikilemleri karşılaştırabilmesini, kendi değer seçimlerinin farkına varabilmesini sağlayabilecek etkinliklerle desteklenebilir.

Öğrencilerin kendi örf ve adetleri çerçevesinde ruhsal, ahlaki, sosyal ve kültürel yönden gelişmelerini ve toplumsal sorunlara karşı duyarlı olmasını amaç edinen Sosyal Bilgiler dersi değer eğitiminde kısa filmler kullanılabilir.

\section{Sonuç}

Teknolojinin ilerlemesi insan yaşamının her alanını etkilediği gibi eğitimi de etkilemiştir. Eğlenme, propaganda, reklam gibi alanlarda kullanılan film ve kısa filmler eğitim aracı olarak da kullanılmaktadır.

Görsel ve işitsel özellikleri bir arada bulunan filmlerin eğitimde kullanımıyla ilgili alan yazın incelendiğinde yapılan çalışmaların olumlu sonuçları olduğu görülmüştür (Öztaş, 2007; Arslan, 2008; Efe, 2010; Çoban, 2011; İnce Yakar 2011; İşcan, 2011; Özer, 2012; Saraç, 2012; Şahin, 2015; Çaykuş, 2015). Gerekli araştırmalar yapıldıktan sonra ortaya çıkan sonuç filmlerin etkili bir öğretim materyali olarak kullanılabildiğidir. Bu konuda öğrencilerin düzeyine uygun bir şekilde hazırlanan kısa filmlerin de eğitimde etkili bir materyal olarak kullanılabileceği öngörülmektedir. MEB kısa filmlerin eğitimde kullanılmasıyla ilgili son zamanlarda çalışmalar yapmaya başlamıştır. EBA bu çalışmaların başında gelmektedir. Ancak bunlar yeterli değildir. Öğretmenler kısa filmlerin seçimi konusunda bilinçli olmalı ve derslerde nasıl kullanılması gerektiği konusunda bilgi sahibi olmalıdır. 
Öğretmenler, öğrencilere görsel ve işitsel etkinliklerde kullanılacak kısa filmlerin sunulmasında önemli bir noktada yer almaktadır. Eğitim ortamında kısa filmlerin kullanımının normal süreli filmlere göre daha pratik olabileceği düşünülmektedir. Filmin dersin konusuna ve öğrencilerin seviyelerine uygunluğu önemli olduğundan öğretmenin ders dışında daha fazla zaman harcamasına sebep olabilmektedir. Ders sirasında filmlerin tamamının izletmesinin mümkün olmadığı durumlarda belirli parçaların izlettirilmesi konunun ve film akışının tam olarak anlaşılması açısından sıkıntılar oluşturabilmekte ve öğretmen izlettirmediği kısımlarla ilgili de bilgi vermek zorunda kalabilmektedir. Aynı zamanda ders esnasında izlenmiş olan filmlerle alakalı tartışma ve değerlendirme aşamaları içinde zamanı ayarlamayı zorunlu hale getirebilmektedir. Öğretmenlerin filmlerden belli k1sımları izletmesi öğrencilerin konunun bütünlüğünü anlamamasına veya öğrencilerin dikkat ve ilgisinin filmin diğer kısımlarına kaymasına sebep olabilir.

Liles'in (2007) araştırmasında belirttiğine göre derse hazırlık aşamasında öğretmenlerin filmleri öğrencilerinden önce izlemeleri zaman gerektirmektedir. Filmlerin zaman, emek ve teknolojik yeterlilik gerektirmesi öğretmenler için önemli bir sinırlılık olduğu vurgulanmıştır. Liles' e (2007) göre filmler zaman, emek ve teknolojik yeterlilik gerektirmektedir. Dersin hazırlık aşamasında öğretmenlerin, filmleri öğrencilerden önce izlemeleri gerekmektedir. Bu hazırlık aşamalarının yanında film izleme esnasında yaşanacak tartışma ve değerlendirme çalışmalarının planlanması için de ek bir süre ayrılması gerekmektedir (akt: Kaya ve Çengelci, 2011). Bu açıdan bakıldığında film kullanımıyla ilgili olan bu tür sınırlılıkları kısa filmlerin azaltabileceği düşünülmektedir.

Kısa filmler zaman açısından kısa olduğu için öğrenciler sıkılmayabilirler. Prensky'nin (2000) yaptığı bir çalışmasında videoların sabırsız olan ve sıkılan öğrenenler için dikkati toplayabilen özelliklere sahip olmasından dolayı tercih edildiği belirtilmiştir. Kısa filmler öğrencilerin ilgisini çekme, etkili ve kalıcı öğrenmelerin gerçekleşmesini sağlayabilmektedir. Hebert ve Peretz (1997) bu konuda eğitimde daha etkili ve kalıcı öğrenmeleri sağlamak, derste öğrencilerin sıkılmasını önlemek ve dersi daha aktif, eğlenceli bir hale getirmek için kullanılan video ve kısa filmlerin beynin gelişim yapısını ve öğrenmesini desteklediğini söylemektedir. Beynin sağ ve sol loblarını da kullanarak işlem yaptığını ifade etmektedir. Kısa filmlerin öğrencilerin beyin gelişimini desteklemesi öğrenme- öğretme sürecini olumlu etkilemektedir (Akbaş, Canoğlu ve Ceylan, 2015).

Ulusoy' un (2009) tarih dersinin işlenişi ve lise öğrencilerinin hangi sıkıntıları yaşadıklarını öğrenmeyi amaçladığı çalışmasında 660 öğrenciye anket uygulanmış ve görüşmeler yapılmıştır. $\mathrm{Bu}$ araştırmanın bulgularından, 428 öğrenci tarih derslerinde konunun geçtiği döneme ait kalıntılar, konuyla ilgili filmler, kısa filmler, belgeseller kullanılmasını istediğini belirtmiştir.

Öğrencilerin gözlem gücünün artması, hayal güçlerini geliştirebilme, olaylara eleştirel açıdan yaklaşabilme, karşıdaki insanın duygu durumlarını anlayabilme açısından kısa filmlerin sağladığı faydalar bulunmaktadır (Kabadayı, 2012).

Yıldırım ve Çalışkan' ın (2017) "Sosyal Bilgiler Dersi Öğretim Programındaki Değerlere ve Değerler Eğitimine İlişkin Öğretmen Görüşleri” adlı çalışmasında 27 öğretmenin 24 tanesi 2005 Sosyal Bilgiler programını değer eğitimi boyutunda yetersiz olduğunu belirtmiştir. Yetersiz bulanların 15 tanesi zaman yetersizliğinden, 9 tanesi de uygulamalı bir değer eğitiminin yapılıyor olmamasından kaynaklandığını belirtmiştir. Değer eğitiminde kullanılan etkinliklerle ilgili ise kısa film izleten öğretmen sayısı 5'tir. Bir öğretmen "Tabi hoşuna da 
gidiyor. Bu tip klsa filmler ile çocuklara çok şeyler verildiğine inaniyorum ben." diyerek değer eğitiminde kısa film kullanımının önemine inandığını vurgulamıştır.

Kurtdede Fidan (2009) “Öğretmen adaylarının Değer öğretimine İlişkin Görüşleri” üzerine yaptığı araştırmada öğretmen adaylarının örnek olması, sinema filmi, tiyatro gibi çalışmaların yapılması gerektiği sonucuna ulaşmıştır. Bu etkinliklere ek olarak kısa filmlerin kullanımıyla ilgili çalışmaların yapılması tavsiye edilmektedir.

Kaya ve Çengelci’nin (2011) “Öğretmen Adaylarının Sosyal Bilgiler Eğitiminde Filmlerden Yararlanmasına İlişkin Görüşleri” isimli çalışmasında öğretmen adaylarının Sosyal Bilgiler dersinde film kullanımının sevgi, işbirliği, dayanışma, özgürlük, demokrasi, barış gibi birçok değerin kazandırılmasına katkı sağladığını belirtmiştir. Öğretmen adaylarının filmlerin Sosyal Bilgiler dersi içeriğiyle ilgili bilgi, beceri ve değerleri desteklemesinden ve katk1 sağlamasından dolayı önemli olduklarını belirttikleri görülmüştür.

Alanyazın incelendiğinde filmlerin Sosyal Bilgiler dersi değer eğitiminde kullanımının olumlu etkilerinden bahsedilmektedir. Filmlerin bir türü olan kısa filmlerin de Sosyal Bilgiler dersi değer eğitiminde kullanımı konusunda aynı olumlu etkileri sağlayacaktır. Kısa filmlerin, filmlere göre zaman ve kurgusu açısından avantajları da dikkate alındığında değer öğretimi açısından etkili bir materyal olduğu söylenebilir.

\section{5.Öneriler}

Öğretmen adaylarına özellikle alan eğitimi derslerinde kısa filmlerin derslerde etkin bir şekilde kullanımına yönelik eğitim verilmelidir. Bu derslerde kısa film kullanımıyla ilgili uygulamalı eğitimler ile öğretmen adaylarının kendi kısa filmlerini nasıl çekebileceklerine ilişkin ayrıntılı bilgiler verilmelidir.

Hizmet içi eğitim seminerlerinde öğretmenlere kısa filmlerin kullanımıyla ilgili seminerler verilebilir.

Sosyal Bilgiler dersinde kullanılabilecek kısa film arşivlerinin oluşturularak öğretmenlerin hizmetine sunulabilir.

Sosyal Bilgiler dersinde kısa film kullanımının etkisine yönelik araştırmalar yapılabilir.

MEB ile bağlantılı olarak Sosyal Bilgiler dersi değer eğitiminde kullanılabilecek uygun materyallerin hazırlandığı bir proje yapılabilir. 


\section{KAYNAKÇA}

ABONO, C. (2016). 5 Major Differences Between Shooting Feature and Short Films. Erişim adresi: https://blog.lookat.io/2016/01/20/5-major-differences-between-shooting-afeature-film-compared-to-a-short-film/ 26.03.2018 tarihinde alındı.

AKBAŞ, O. (2011). Bir Öğrenme Nesnesi Olarak Eğitsel Kısa Filmler: Öğretmen Adaylarının Çektikleri Eğitsel Kısa Filmler Üzerine Bir Değerlendirme. Gazi Üniversitesi Endüstriyel Sanatlar Eğitim Fakültesi Dergisi, 27, 15-27.

AKBAŞ, O., CANANOĞLU, S., CEYLAN, M. (2015). Eğitsel Kısa Film ve Videoları Yeniden Düşünmek: Eğitsel Kısa Film ve Video Yarışmasına İlişkin Bir Değerlendirme. Kuramsal Eğitimbilim Dergisi, 8(2), 282-296.

AKPINAR, Y. (2005). Bilgisayar Destekli Eğitimde Uygulamalar (2.Bask1). Ankara: Anı Yayıncilik.

ALADAĞ, S. (2009). İlköğretim Sosyal Bilgiler Öğretiminde Değer Ĕ̆itimi Yaklaşımlarının Öğrencilerin Sorumluluk Değerini Kazanma Düzeyine Etkisi. Doktora Tezi. Gazi Üniversitesi Eğitim Bilimleri Enstitüsü.

ALICIGÜZEL, İ. (1998). Çăgdaş Okulda Ĕ̆itim Ve Öğretim. İstanbul: Sistem Yayınc1lık.

ALKAN, C. (1998). Eğitim Teknolojisi. Ankara: Anı Yayıncılık.

ARSLAN, Ö. (2008). Illkögrretim 8.sınıf T.C. Inkılap Tarihi Ve Atatürkçülük Ders Öğretiminde Görsel Ve İşitsel Materyal Kullanımının Öğrencilerin Akademik Başarıları ve Hatırda Tutma Düzeyleri Üzerine Etkisi. Yüksek Lisans Tezi. Dokuz Eylül Üniversitesi Eğitim Bilimleri Enstitüsü.

AYDIN, M, Z., AKYOL GÜRLER, Ş. (2014). Okulda Değerler Eğitimi YöntemlerEtkinlikler- Kaynaklar (4. Basım). Ankara: Nobel Yayıncılık.

BİRKÖK, M, C. (2008). Bir Toplumsallaşma Aracı Olarak Eğitimde Alternatif Medya Kullanımı: Sinema Filmleri. Uluslararası Insan Bilimleri Dergisi. 5(2) 1-10

BRUNER, J. (2014). Eğitim süreci. (Çev. Talip Öztürk). Ankara. Pegem Akademi (Eserin Orijinali 2008' de yayımlandı).

ÇAKIROĞLU, Ü., GÜVEN, B., AKKAN, Y. (2008). Öğretmen Adaylarının Web Tabanlı Öğrenme Ortamında Öğrenme Nesnelerini Kullanma Şekillerinin Belirlenmesi. [http://ietc2008.home.anadolu.edu.tr/ietc2008/222.doc]

ÇAYKUŞ, E. (2015). Öğrenci Kişilik Hizmetleri Kavramlarının Yaratıcı Drama Programı Kapsamında Araştırllması. Yüksek Lisans Tezi. Cumhuriyet Üniversitesi Eğitim Bilimleri Enstitüsü.

ÇOBAN, Z. (2011). Tarih Derslerinde Tarihi Film Ve Dizilerin Kullanımına İlişkin Öğretmen Ve Öğrenci Görüşleri, Yüksek Lisans Tezi, Karadeniz Teknik Üniversitesi Eğitim Bilimleri Enstitüsü.

EFE, Ü. (2010). Sosyal Bilgiler Öğretiminde Filmlerin Kullanımı, Yüksek Lisans Tezi, Niğde Üniversitesi Sosyal Bilimler Enstitüsü. 
ETIKAN, H. (2003). Klsa Filmin Suçu Ne? Erişim: http://www.kisafilm.com/2003-y-1--yazlar-.html adresinden 26.01.2018 tarihinde alınmıştır.

EVCI, S. (2007). Ifsak Klsa Film Atölyesi Ders Notları.İstanbul: İFSAK Yayınları.

GILL, C. N., COLLEGE, C. (2014). Using Short, Authentic Film to Teach Culture. CLV Educator Webinar Series. Erişim adresi: http://www.concordialanguagevillages.org/pdf/CLV Presentation ForeignFilm.pdf 26.06.2018 tarihinde alınd.

GÖMLEKSİZ, M. N. ve CÜRO, E. (2011). Sosyal Bilgiler dersi öğretim programında yer alan değerlere ilişkin öğrenci tutumlarının değerlendirilmesi. Uluslararası İnsan Bilimleri Dergisi, 8 (1), 95-134.

GÜZELOĞLU, O. (2008). Klsa Film Nedir? Erişim: http://kisafilm.blogspot.com.tr/2008/01/ksa-film-nedir.html adresinden 28.02.2018 tarihinde erişilmiştir.

İNCE YAKAR, H. (2011). Destanların Öğretiminde Film Kullanımının Ortaöğretim Türk Edebiyatı Derslerindeki Akademik Başarıya Etkisi. Doktora Tezi. Gazi Üniversitesi Eğitim Bilimleri Enstitüsü.

İŞCAN, A. (2011). Yabancı Dil Olarak Türkçe Öğretiminde Filmlerin Yeri Ve Önemi. Turkish Studies Dergisi,. 6/3. 939-948.

KABADAYI, L. (2012). The role of short film in education. Procedia - Social and Behavioral Sciences 47 ( 2012 ) $316-320$.

KAYA, E., ÇENGELCİ, T., (2011). Öğretmen Adaylarının Sosyal Bilgiler Eğitiminde Filmlerden Yararlanılmasına İlişkin Görüşleri. Sosyal Bilgiler Eğitimi Araştırmaları Dergisi. 2(1), 116-135

KAYNAR, T. (1993). Önce Kisa Film Vardl, İstanbul, Antrakt Yayınları.

KORKMAZ, M. (2014). Din Öğretimi Teknolojisi ve Materyal Geliştirme, Kayseri, Tezmer YAYINLARI.

KORKMAZ, M. (2017). Din Dersi Öğretmenlerinin Bir Öğretim Materyali Olarak Filmleri Kullanma Durumları. Bilimname XXXIII, 2017/1, 35-66.

KURTDEDE FIDAN, N. (2009). Öğretmen Adaylarının Değer Öğretimine İlişkin Görüşleri. Kuramsal Eğitimbilim, 2 (2), 1-18.

NASH, P. (2013). Kısa Film Senaryosu Yazmak. (B. Baysal, Çev.) İstanbul: Kalkedon Yayınları. (Eserin Orijinali 2012' de yayımland1).

OKUMUŞ, S. (2014). Yeni Medya Ve Kısa Film Olgusu. Yüksek Lisans Tezi, İstanbul Kültür Üniversitesi Sosyal Bilimler Enstitüsü.

ÖNEN ÖZTÜRK, F., (2017). Fen- Toplum Temelli Eğitsel K1sa Filmler Üzerine Bir Çalışma: Fen Bilgisi Öğretmenliği Örneği. Marmara Üniversitesi Eğitim Fakültesi Dergisi.13(2): 633-649.

ÖZER, S. (2012). Sosyal Bilgilerin Öğretiminde Çizgi Filmlerin Kullanımı, Yüksek Lisans Tezi, Niğde Üniversitesi Eğitim Bilimleri Enstitüsü. 
ÖZGÖKBEL BİLİş, P. (2011). Çizgi Filmlerde Temsil Edilen Toplumsal Değerler Sistemi. Ege Üniversitesi Sosyal Bilimler Enstitüsü Radyo Televizyon Anabilim Dalı. Yayınlanmamış Doktora Tezi

ÖZÖN, N. (1981).Sinema ve TV Terimleri Sözlüğ̈̈, Ankara, TDK Yayınları.

ÖZTAŞ, S. (2007). Tarih Öğretimi ve Filmler: Tarih Öğretiminde Film Kullanılmasının Ögrenci Başarısı Üzerindeki Etkisi. Doktora Tezi, Gazi Üniversitesi Eğitim Bilimleri Enstitüsü.

ÖZTAŞ, S. (2008). “Tarih Öğretimi ve Filmler”, Kastamonu Eğitim Fakültesi Dergisi, 16 (2), 543-556.

ÖZTÜRK SAMUR, A. (2011). Değerler Ĕgitimi Programının 6 Yaş Çocuklarının Sosyal ve Duygusal Gelişimlerine Etkisi. Yayınlanmamış Doktora Tezi. Selçuk Üniversitesi Sosyal Bilimler Enstitüsü.

ÖZTÜRK, C. (2009). Sosyal Bilgiler: Toplumsal Yaşama Disiplinlerarası Bir Bakış. (Editör: Cemil Öztürk.). Sosyal Bilgiler Öğretimi Demokratik Vatandaşlık Eğitimi içinde (131). Ankara: Pegem Akademi Yayıncılık.

ÖZTÜRK, S. (2009). Kısa Filmin Oluşum Sürecinde Ses Öğelerinin Kullanımı. Yüksek Lisans Tezi, Maltepe Üniversitesi Sosyal Bilimler Enstitüsü.

SARAÇ, H. (2012). Yabancı Dil Öğretimi Sürecinde Sanatsal Filmler. IDİL, Cilt 1, Say1 4 / Volume 1, Number 4. DOI: 10.7816/idil-01-04-03

ŞAHIN, C. (2015). Ortaokul Öğrencilerinin Dinleme Becerilerinin Geliştirilmesinde Kısa Filmlerin Etkisi. Dil ve Edebiyat Eğitimi Dergisi, 10, 66-79.

TDK. (2018). Bilim ve Sanat Terimleri Ana Sözlüğü. Erişim: http://www.tdk.org.tr/index.php?option=com_bilimsanat\&view=bilimsanat Adresinden 03.02.2018 tarihinde elde edilmiştir.

TOZLU, N. (1992). Eğitim Problemlerimiz Üzerine Düşünceler, Yüzüncü Yıl Üniversitesi Ë̆itim Fakültesi, Van.

ULUSOY, K. (2009). Lise Öğrencilerinin Tarih Dersinin İşlenişi İle İlgili düşünceleri(Ankara Örneği). Ç.Ü. Sosyal Bilimler Enstitüsü Dergisi, Cilt 18, Sayı 1, s.417-434

What is the Difference between Short Films and Feature Films Length Films?. (t.y.). The Sheffield İnstitute For The Recording Arts. Erişim: http://www.sheffieldav.com/education/short-films-vs-feature-length-films adresinden 23.03.2018 tarihinde alınd1.

YAŞAR, Ş. ve GÜLTEKİN, M. (2006). Sosyal Bilgiler Öğretiminde Araç- Gereç Kullanımı. Hayat Bilgisi ve Sosyal Bilgiler Öğretimi Yapılandırmacı Bir Yaklaşım içinde (287311). (Editör: Cemil Öztürk.). Ankara: Pegem Akademi Yayıncılık.

YEŞILYURT, Ş. (2016). Türkçenin yabancı dil olarak öğretiminde duygu durumlarını yansitan kısa filmlerin oluşturulması ve öğrenci başarısına etkisi. Yayımlanmamış Doktora Tezi. Gazi Üniversitesi Eğitim Bilimleri Enstitüsü. 
YILDIRIM, Y. ve ÇALIŞKAN. H. (2017). Sosyal Bilgiler Dersi Öğretim Programındaki Değerlere ve Değerler Eğitimine İlişkin Öğretmen Görüşleri. Journal of Multidisciplinary Studies in Education, 1(1), 7-23. 


\section{EKLER:}

Not: Ekler kısmında yer alan filmler EBA platformu içinde yer alan kısa film yarışmalarının içerisinden ödüllü olanlar arasından seçilmiştir. Filmlerin seçiminde öğrencilerin durumları, film içeriğinin uygunluğu dikkate alınmış ve Sosyal Bilgiler alan eğitim uzmanından görüş alınmıştır.

\section{Etkinlik Örneği 1}

Ders: Sosyal Bilgiler

\section{Sinıf: 4}

Kazanım: Başkalarının duygu ve düşüncelerini saygı ile karşılar.

Ünite/Konu: Kendimi Tanıyorum

Değer: Duygu ve düşüncelere sayg1, aile büyüklerine saygı ve hoşgörü

\section{Film Adı: Kozalak}

Film Süresi: 4 dakika 24 saniye

Film: Duygu, güneşli bir günde parkta bir banka oturmuştu. Elindeki cep telefonuyla oyun oynuyordu. Birkaç dakika geçtikten sonra annesi de parka geldi. Gülümseyerek Duygu'nun yanına oturdu. Duygu'da annesine gülümsedi ama hiçbir şey söylemedi. Annesi birkaç saniye sonra eliyle işaret ederek "Kızım şu kozalağı getirir misin?" diye sordu. Duygu gülümseyerek "Tabi" dedi ve yerdeki o kozalağı alıp annesine getirdi. Annesine getirdikten sonra elindeki telefon ile oynamaya devam etti. Annesi Duygu'dan tekrar bir kozalak getirmesini istedi. Duygu biraz suratını asarak istediği kozalağı getirdi ama bu sefer gülümsemedi. Annesi tekrar farklı bir kozalak getirmesini istedi. Duygu sürekli aynı şeyi istediği için annesine kızdı ve ona "Çocuk musun sen çek git başımdan ya off!" diye bağırdı. Annesi Duygu'nun bu davranışına üzüldü ve gitti. Duygu ise elindeki telefonuyla oynamaya devam etti. Birkaç dakika sonra annesi elinde bir fotoğrafla geldi. Fotoğrafin arkasında bir not yazıyordu. O fotoğrafı Duygu'ya uzattı ve okumasını istedi. O notta: "Sevgili kızım bugün her zamanki gibi senin en çok sevdiğin parktayız ama bugün çok özel bir gün. Çünkü bugün sayı saymayı öğrendin. Bahçedeki tüm kozalakları sayıp bana tek tek toplattırdın. Seni çok seviyorum annen.” Duygu notu okuduktan sonra annesine saygısızlık ettiği ve onu üzdüğü için pişman oldu. Yaptığı yanlışı fark ederek annesine sarıldı.

Ön Hazırlık: Kullanılacak araç gereçler hazırlanır (Bilgisayar, Projeksiyon, Akıllı tahta vs kontrol edilir).

-Öğretmen tarafından etkinliğin amacı açıklanır.

-Kısa film izlenmeden önce öğretmen tarafından öğrencilere “ Aynı şeyi kısa aralıklarla tekrar tekrar birinden isteseniz sizce karşı taraf size nasıl bir tepki verir?" sorusu sorulur ve yanitlar alınır. 
Uygulama: Kısa film hep birlikte izlenir. Film bittikten sonra öğrencilere değerlendirmeye geçilir. Öğrencilere değerlendirme soruları sorulur ve tartışmaları istenir.

\section{Değerlendirme:}

1.Bu kısa filmden çıkardığınız dersler nelerdir?

2.Benzer bir olaylarla karşılaştığınızda nasıl davranırdınız?

3. Ailemize verdiğimiz değerin farkında mıyı?

Öğretmen "Anne/baba veya arkadaşlarınızı kırdığınız ve kötü davrandığınız bir anınız varsa özür mektubu hazırlayınız.” der ve gönüllü öğrencilerden mektuplarını okumalarını ister.

\section{Etkinlik Örneği 2}

Ders: Sosyal Bilgiler

\section{Sinıf: 7}

Ünite/Konu: İletişim ve İnsan İlişkileri

Kazanım: 1.İletişimi, olumlu olumsuz etkileyen tutum ve davranışları fark ederek kendi tutum ve davranışlarıyla karşılaştırır.

2.İnsanlar arasında kurulan olumlu ilişkilerde iletişimin önemini fark eder.

Değer: Sayg1, sevgi, hoşgörü, sorumluluk

Film Adl: Yaklaş

Film Süresi: 6 dakika 51 saniye

Film: Ali ve Hasan aynı sınıfta okuyan ama birbirini sevmeyen, sürekli kavga eden iki öğrencidir.

Bir gün Hasan okul bahçesinde Ali’ye bilinçli olarak çarptı. Bunun üstüne Ali sinirlendi ve tam Hasan ile kavga edecekken sınıftan farklı bir arkadaşı geldi. Ali'yi o ortamdan uzaklaştırıp sınıfa götürdü... Farklı bir gün Ali ve Hasan tuvalet önünde sıra bekliyorlardı. Tuvaleten bir kişi çıktığı an Hasan, Ali'yi ittirdi. Kavga etmeye başlamışlardı. Sonunda Ali yere düştü ve Hasan onunla dalga geçerek tuvalete girdi... Okul bahçesinde öğrenciler futbol maçı yapıyorlard1. Oyun esnasında Ali ve Hasan birbirlerini ittirdiler. İkisinin kavga etmesi üzerine diğer arkadaşları da birbirleriyle kavga etmeye başlamışlardı. Öğretmenleri bu olaydan sonra onları uyardı. Ders esnasında Ali ve Hasan'ı aynı sıraya oturttu. Bu iki öğrenci aynı sırada oturmak istemiyordu. Ancak aradan biraz zaman geçtikten sonra kavga etmeleri azalmaya başlamıştı... Sınıf içinde Hasan yediği bisküviyi gizlice Ali'nin defterine koydu. $\mathrm{Bu}$ arkadaşlığa atılan ilk adımdı. Ali bisküviyi görünce sevindi ve yemeye başladı. Başka bir gün öğretmen, Ali ve Hasan'ı tahtaya kaldırmıştı. Ali soruyu hemen çözüp bitirdi. Hasan ise hepsini yapamamıştı. Ali, Hasan'a yardım etti ve gülümsedi. Zaman geçtikçe birbirlerine daha iyi davranmaya başlamışlardı. Okul bahçesinde oynarken birbirlerine yardım ediyorlardı. Bu şekilde zaman geçtikçe Ali ve Hasan yakın arkadaş oldular. Birbirleriyle kavga etmeden iyi bir arkadaş olabilmek için birbirlerine saygı duymak gerektiğini, sevginin ve arkadaşlığın önemini anlamışlardı. 


\section{Ön Hazırlık:}

- Kullanılacak araç gereçler hazırlanır (Bilgisayar, Projeksiyon, Akıllı tahta vs kontrol edilir).

- Etkinliğin amacı açıklanır.

Uygulama: Kisa film hep birlikte izlenir. Film bittikten sonra öğrencilere değerlendirmeye geçilir. Öğretmen tarafindan öğrencilere değerlendirme soruları sorulur ve tartışmaları istenir.

\section{Dĕgerlendirme:}

1.İzlediğiniz kısa filmden neler öğrendiniz?

2. İnsanlar birbirine kibar ve saygılı davrandıklarında nasıl bir çevre oluşur?

3. Kısa filmdeki bu olayı gerçek yaşamda uygulaması ne kadar zor?

4.Bu filmdeki öğrenciler birbirleriyle kavga etmeye devam etselerdi neler olabilirdi?

5.İnsanların birbirlerine sevgi ile yaklaşmaları sorunların çözümüne nasıl yardımcı olur?

6. Sevgi ve saygının sorunları çözebileceğine inanıyor musunuz?

Öğretmen "Bir arkadaşınızla yaşadığınız sorununuzun sebebini düşünün ve bunun çözüm yollarının neler olabileceğini sıra arkadaşınızla tartışınız.” der. Öğrencilerin tartışmaları bittikten sonra sorunlar ve çözüm yolları üzerine sınıfça konuşma yapılır. 